\title{
Fisheries E Society

\section{Training on how to make floating cage net for sea urchin culture at Desa Pisou, Central Sulawesi, Indonesia}

Pelatihan pembuatan keramba jaring apung untuk pembudidayaan landak laut (sea urchin) di Desa Pisou, Sulawesi Tengah, Indonesia

\author{
Alfi Sahri Remi Baruadi ${ }^{1}$, Sumrin $^{1}$, La Nane $^{1 *}$ \\ ${ }^{1}$ Jurusan Manajemen Sumber Daya Perairan, Fakultas Perikanan dan Ilmu Kelautan, Universitas Negeri Gorontalo
}

\section{ARTICLE INFO}

\section{Keywords:}

Desa Pisou; Floating Cage Net; Sea Urchin

\section{How to cite}

Baruadi, A. S. R., Sumrin, S., \& Nane, L. (2021). Training on how to make floating cage net fot sea urchin culture at Desa Pisou, Central Sulawesi, Indonesia. Fisheries and Society, 1(1), 1-4.

Received: $2020-12-02$

Accepted: 2021-01-13

\begin{abstract}
Sea urchin is an abundant fisheries resources in Pisou Village, Pagimana District, Central Sulawesi. This abundance is caused by the high productivity of sea urchins and the lack of utilization by the local community. The high density of sea urchins causes the poor quality of gonad and taste. This is mainly caused by the insufficient availability of food in the nature that can be only improved by aquaculture. This community empowerment was conducted in the Pisou Village for 5 weeks from February-March 2020. The aim of this program is to cultivate sea urchins in improving the quality of sea urchin gonad by aquaculture. Another goal is to educate the local fishers on how to culture and utilized the gonad a seafood and crackers. The result of this activity is the availability of floating net cages at Desa Pisou Village that can be used for sea urchin cultivation.
\end{abstract}

This journal is licensed under a Creative Commons Attribution 4.0 International License.

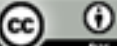

\section{PENDAHULUAN}

Seiring dengan pertambahan populasi penduduk Indonesia dewasa ini, permintaan bahan makanan yang mengandung protein juga terus meningkat. Di sisi lain, penyakit busung lapar yang umum dikenal dengan istilah kurang gizi atau gizi buruk akibat malnutrisi semakin meningkat dan mengkhawatirkan sejumlah masyarakat. Laporan terakhir dari (Choliq et al., 2020) menyebutkan bahwa masalah stunting akibat kekurangan gizi masih menjadi masalah serius di negara berkembang khususnya Indonesia.

Indonesia sebagai negara maritim dengan panjang pantai terpanjang kedua di dunia $108.000 \mathrm{~km}^{2}$ (Setiawan et al., 2020; Wahyudi et al., 2020). Wilayah laut tersebut dikaruniai beragam sumber daya laut yang dapat dimanfaatkan sebagai bahan pangan. Sumber daya tersebut dapat berupa sumber daya ikan maupun non ikan yang memiliki protein yang baik untuk kesehatam. Salah satu produk perikanan non-ikan yang masih minim dan belum di manfaatkan dengan baik di Indonesia adalah landak laut (Aimatuzzahro et al., 2020; Mulis et al., 2020; Nane, 2019). Di sisi lain, landak laut atau dikenal dengan nama perdagangan sea urchin sangat melimpah di Indonesia (Bachtiar et al., 2020). Di beberapa negara maju, seperti chile, spanol, amerika, dan

\footnotetext{
*Sur-el korespondensi: lanane@ung.ac.id
} 
Jepang telah memanfaatkan telur landak laut ini secara optimal. Hal ini didukung oleh aktivitas pembudidayaan landak laut tersebut yang juga sudah cukup maju dan terus berkembang.

Sementara di Indonesia, landak lautnya dibiarkan melimpah begitu saja tanpa ada pemanfaatan sama sekali. Pemanfaatan landak laut yang sedikit intensif hanya dilakukan oleh masyarakat yang tinggal di kepulauan Wakatobi. Laporan Nane dan Paramata (2020) menyebutkan bahwa pemanfaatan landak laut bahkan telah mengalami overfishing karena tingginya penangkapan.

Akan tetapi, secara umum di Indonesia pemanfaatan landak laut untuk penganan. Terutama konsumsi segar maupun olahan sangat minim (Baruadi \& Nane, 2020). Akibatnya landak laut melimpah di alam dan mengakibatkan kualitas telurnya menurun (Nane et al., 2020). Hal ini dikarenakan oleh kompetisi di antara kumpulan atau gerombolan landak laut yang saling berkompetisi mencari makanan yang stoknya terbatas. Konsekuensinya, telur landak laut menjadi kecil dan berwarna hitam, karena mendapatkan asupan makanan yang sedikit dan ukuran telurnya menjadi kecil.

Untuk melakukan kegiatan pemanfaatan, atas landak laut yang melimpah tersebut. Maka perlu dilakukan kegiatan pembudidayaan terkontrol. Dengan demikian kebutuhan pakan dari landak laut yang dibudidaya dapat terpenuhi dengan baik tanpa harus saling berkompetisi dengan biota landak laut lainnya. Tujuan kegiatan pembudayaan ini adalah dimaksudkan untuk memperbaiki kualitas telur landak laut yang melimpah di alam agar bisa dimanfaatkan dan dikonsumsi. Serta memperbesar dan memperbaiki kualitas telur landak laut itu sendiri agar menghasilkan landak laut yang unggul.

\section{METODE PELAKSANAAN}

Kegiatan pengabdian ini dilaksanakan dengan metode pelatihan. Pelaksanaannya dilakukan di Kantor Desa Pisou, Kecamatan Pagimana Sulawesi Tengah. Pelaksanaan kegiatan ini dilakukan selama 5 minggu pada bulan Februari-Maret 2019 dengan melibatkan 15 mahasiswa KKN-Universitas Negeri Gorontalo. Metode yang digunakan dalam kegiatan ini dilakukan dengan menggabungkan aspek teori dan praktik yang dilakukan dalam beberapa tahapan:

1. Tahap edukasi

Tahap edukasi ini dilakukan dalam bentuk pemberian materi kepada masyarakat. Materi yang disampaikan berupa informasi tentang aspek biologi, ekologi, dan penanganan landak laut. Termasuk pemberian gambaran tentang konstruksi keramba jaring apung yang cocok untuk landak laut.

2. Tahap Praktik konstruksi KJA

Pada fase ini, masyarakat dilatih mendesain atau membangun keramba jaring apung untuk pembudidayaan landak laut.

3. Tahap Pemasangan

Tahap pemasangan masyarakat diedukasi tentang Teknik penempatan keramba jaring di lokasi yang tepat. Pemilihan lokasi yang tepat akan memengaruhi tingkat keberhasilan kegiatan budi daya landak laut. Apek utama yang perlu diperhatikan adalah gelombang, salinitas dan ketersediaan pangan.

\section{HASIL DAN PEMBAHASAN}

Edukasi. Edukasi kepada nelayan tentang landak laut telah berhasil dilaksanakan dengan baik (lihat Gambar 1). Indikator keberhasilan tersebut dapat diukur dari adanya perubahan pola pikir masyarakat terhadap landak laut yang sebelumnya dianggap beracun dan tidak layak untuk dikonsumsi berubah menjadi anggapan positif dan respon positif bahwa landak laut memiliki nilai ekonomis dan dapat dimanfaatkan sebagai bahan pangan dan dapat diolah menjadi berbagai olahan pangan lainnya seperti kerupuk, dll.

Selain itu, masyarakat juga telah mendapatkan informasi yang memadai tentang aspek biologi, ekologi, dan penangkapan landak laut. Termasuk cara reproduksi landak laut. Hal ini dapat dilihat dari banyaknya 
pertanyaan dan respon-respon positif dari para nelayan yang bermaksud menglarifikasi kesalahan-kesalahan pandangan dan anggapan terkait dengan pengetahuan dan pengalaman-pengalaman mereka selama bersentuhan dengan landak laut khususnya terkait dengan duri landak laut yang informasinya dapat membunuh dan mematikan bila disentuh karena mengandung racun.

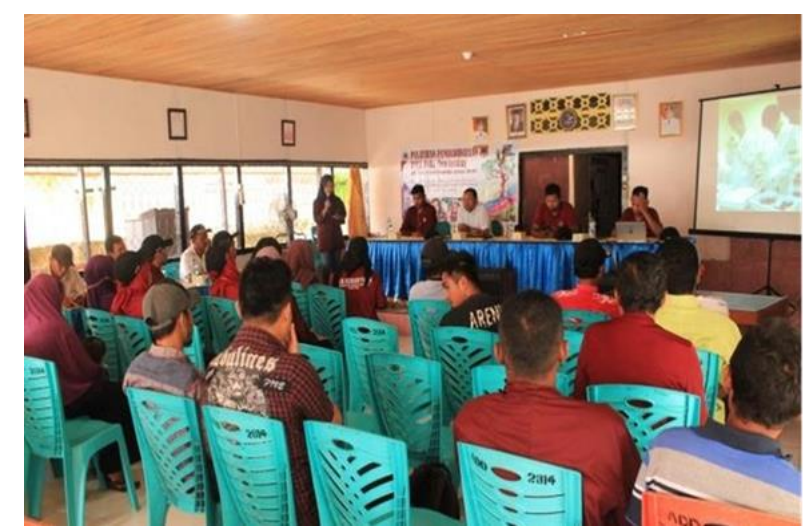

Gambar 1. Edukasi pembudidayaan landak laut

Praktik Konstruksi dan Pemasangan KJA. Kegiatan praktik konstruksi keramba jarng apung pada kegiatan pengabdian ini berhasil dilakukan dengan baik. Selain itu, masyarakat juga telah memahami Teknik dan cara mendesain atau membuta keramba jarring apung dengan bahan dasar rangka dari pipa paralon dan jarring nilon. Selain itu, nelayan juga telah mengetahui lokasi yang tepat untuk peletakan keramba jarring apung yang sesuai untuk budidaya landak laut.
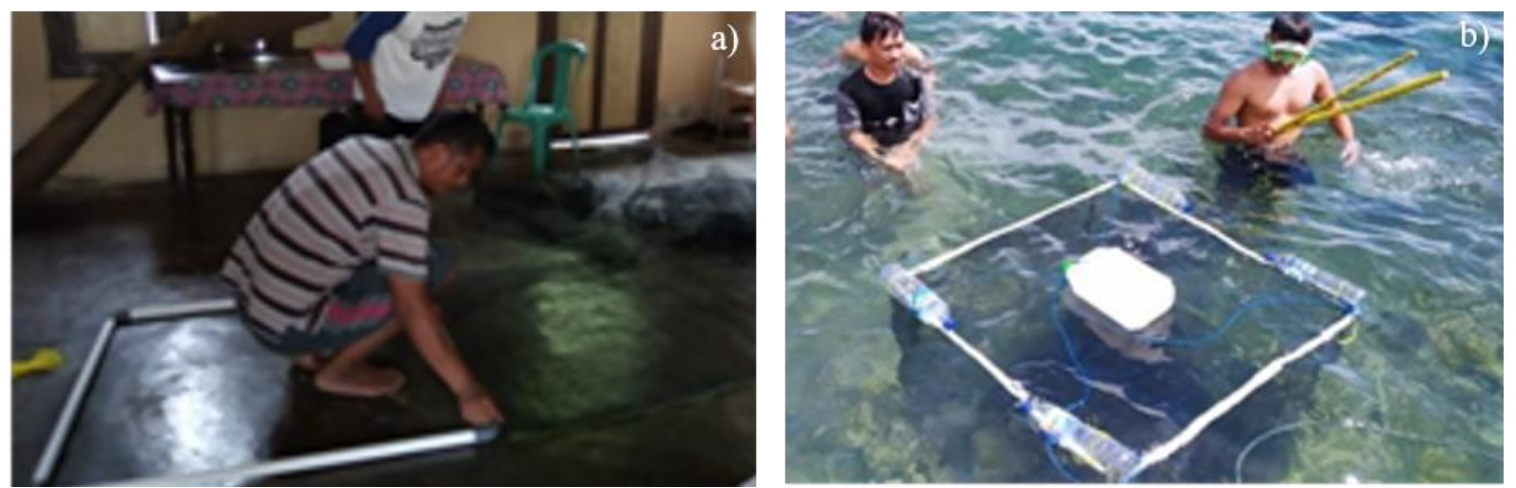

Gambar 2. Praktik keramba jarring apung: a). Pemasangan rangka pipa paralon dan jarring KJA; b) Pemasangan KJA di lokasi yang telah ditentukan untuk pembudidayaan landak laut.

Pembuatan Kerupuk Landak Laut. Kegiatan diversifikasi olahan pangan dari telur landak laut dilaksanakan untuk menanamkan pengetahuan ibu-ibu nelayan terkait pemanfaatan telur landak laut pasca panen landak laut yag dibudidayakan di KJA. Dengan demikian, rantai kegiatan pembudidayaan landak laut bukan saja hanya dipasarkan secara segar, tapi juga dapat dipasarkan telurya dalam bentuk olahan kerupuk.
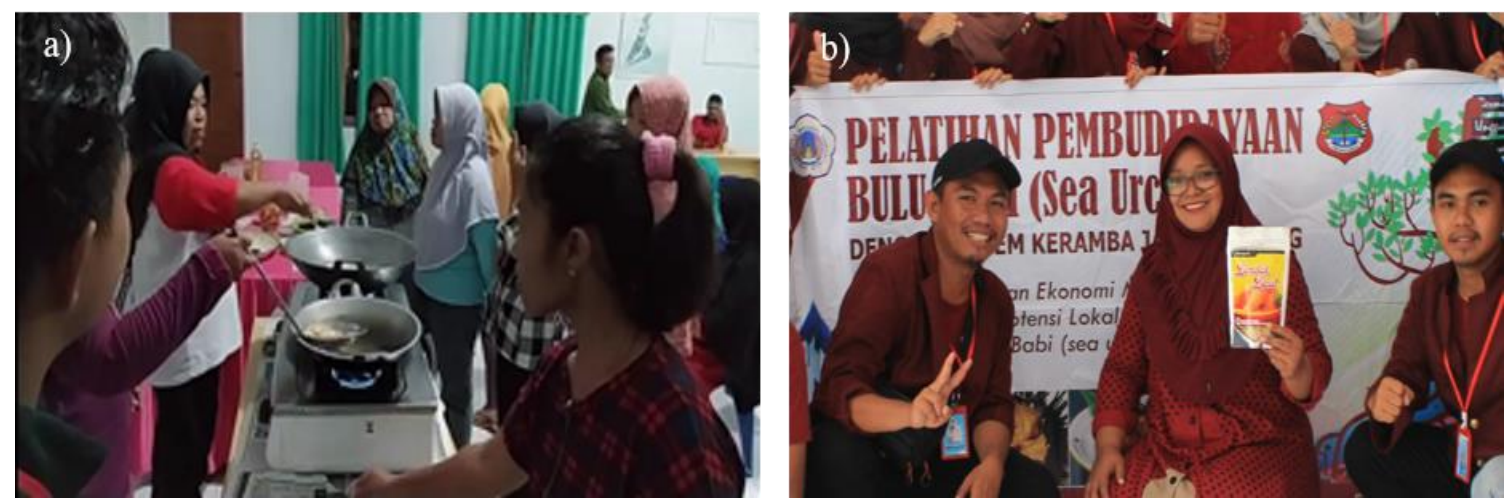

Gambar 3. Diversifikasi olahan landak laut: a) Proses penggorengan kerupuk landak laut; b) kemasan kerupuk telur landak laut yang sudah siap dipasarkan ke konsumen 


\section{KESIMPULAN}

Masyarakat pesisir pada dasarnya mampu beradaptasi dengan segala kemajuan dan perubahan. Hanya saja, keterbatasan informasi dan pengetahuan selalu menjadi dasar penyebab kesenjangan utama. Minimnya pemanfaatan landak laut di Desa Pisou tak terlepas dari minimnya informasi yang masuk ke masyarakat. Hal ini kemudian menyebabkan masyarakat sulit memanfaatkan potensi yang ada. Sekalipun potensi tersebut dapat dimanfaatkan untuk pangan atau diperjualbelikan untuk meningkatkan ekonomi masyarakat setempat. Selain itu, penulis juga menyampaikan bahwa kegiatan pelatihan pembuatan keramba jaring apung untuk pembudidayaan landak laut (sea urchin) pada masyarakat Desa Pisou ini cukup berhasil mencapai tujuan kegiatan. Keberhasilan kegiatan tersebut diukur dari 2 hal utama. Pertama, semua masyarakat dan cukup kooperatif dan antusias mengikuti seluruh tahapan kegiatan. Kedua, semua materi yang disampaikan telah dipahami dan dimengerti dengan baik oleh peserta.

\section{UCAPAN TERIMA KASIH}

Penulis mengucapkan banyak terima kasih kepada LPPM Universitas Negeri Gorontalo atas segala bantuan dan dukungannya dalam pelaksanaan kegiatan ini. Sehingga kegiatan ini dapat terlaksana dengan baik.

\section{REFERENSI}

Aimatuzzahro, A., Sufadjari, A., \& Nurchayati, N. (2020). Keragaman bulu babi (Echinoidea) di perairan pantai Pulau Merah Pesanggaran Pesanggaran Banyuwangi. Biosense, 3(2), 37-50.

Bachtiar, I., Merta, I. W., Kusmiyati, K., \& Syachruddin, A. (2020). Komunitas Echinodermata di kawasan intertidal Pantai Mandalika Pulau Lombok, Indonesia. Depik, 9(2), 156-163. https://doi.org/10.13170/depik.9.2.13582

Baruadi, A. S. R., \& Nane, L. (2020). Edukasi Pemanfaatan Bulu-Babi (Sea Urchin) Melalui Budi Daya Keramba Jaring Apung. Jurdimas Royal, 3(2), 169-174. https://doi.org/10.33330/jurdimas.v3i2.666

Choliq, I., Nasrullah, D., \& Mundakir, M. (2020). Pencegahan stunting di Medokan Semampir Surabaya melalui modifikasi makanan pada anak. Humanism: Jurnal Pengabdian Masyarakat, 1(1), 31-40. http://journal.um-surabaya.ac.id/index.php/HMN/article/download/4544/2678

Mulis, M., Lamadi, A., \& Nane, L. (2020). Pelatihan Pembuatan Bakso Telur Landak Laut (Sea Urchin) sebagai Upaya Peningkatan Ekonomi dan Gizi Masyarakat Pesisir di Desa Kotajin, Gorontalo Utara. Jurnal Abdidas, 1(4), 215-221. https://doi.org/10.31004/abdidas.v1i4.46

Nane, L. (2019). Efisiensi Mesin Teknologi Sapurata Dalam Mengoptimalisasi Produksi Inovasi Pangan Kukure Di Pulau Barrang Lompo, Makassar. https://doi.org/10.31230/osf.io/q8spg

Nane, L., Baruadi, A. S. R., \& Mardin, H. (2020). Density of the blue-black urchin Echinotrix diadema (Linnaeus, 1758) in Tomini Bay, Indonesia. Tomini Journal of Aquatic Science, 1(1), 16-21. https://doi.org/10.37905/tjas.v1i1.5939

Nane, L., \& Paramata, A. R. (2020). Impact of Overfishing on Density and Test-Diameter Size of the Sea Urchin Tripneustes gratilla at Wakatobi Archipelago, South-Eastern Sulawesi, Indonesia. ILMU KELAUTAN: Indonesian Journal of Marine Sciences, 25(2), 53-56. https://doi.org/10.14710/ik.ijms.25.2.53-56

Setiawan, K. T., Winarso, G., Ginting, D. N. B. R., Manessa, M. D. M., Surahman, S., Anggraini, N., Hartuti, M., Asriningrum, W., \& Parwati, E. (2020). Pemanfaatan metode semi-analitik untuk penentuan (utilization of semi-analytical methods for determining batimetry using high resolution satellite images). 17(2), 135-147.

Wahyudi, A. J., Rahmawati, S., Irawan, A., Hadiyanto, H., Prayudha, B., Hafizt, M., Afdal, A., Adi, N. S., Rustam, A., Hernawan, U. E., Rahayu, Y. P., Iswari, M. Y., Supriyadi, I. H., Solihudin, T., Ati, R. N. A., Kepel, T. L., Kusumaningtyas, M. A., Daulat, A., Salim, H. L., ... Kiswara, W. (2020). Assessing Carbon Stock and Sequestration of the Tropical Seagrass Meadows in Indonesia. Ocean Science Journal, 55(1), 85-97. https://doi.org/10.1007/s12601-020-0003-0 